\title{
Rethinking belonging: a Mediterranean disaffection
}

\section{Carme Colomina}

Abstract: The consensus on what the EU is or should be is broken. In the present time of the politics of emotions, belonging is an individual experience. Where do we feel we fit in? Where and who do we feel attached to? The EU's political identity is always in-the-making because citizens' feelings of belonging have been evolving. Was there any kind of peripheral identity during all the years of the economic crisis? Were the different understandings and perceptions of the 2008 financial and political crunch influencing the construction of identity? And did they do so in a contradictory or opposite way in different parts of the European territory? In the public discourse (media and politics), the economic crisis was always framed as somebody else's crisis. Explained by internal divides: North and South, debtors and creditors, core and periphery. However, within this dual narrative, the EU Southern political representatives did not attempt to build a common Southern identity. The peripheral countries of Mediterranean Europe were blamed as all of a kind, but their governments were unable to construct a common front.

Keywords: Identity, belonging, narrative, legitimacy, South, periphery, austerity, 'indignados', otherness, sovereignty.

Author: Carme Colomina is a research fellow on the European Union, disinformation and global politics at the Barcelona Centre for International Affairs (CIDOB). She is also visiting professor at the College of Europe in Bruges, Belgium, where she teaches a course on Communications Management in the European Union. Before joining CIDOB, she worked for two decades as a journalist, being correspondent in Brussels and special envoy to dozens of international summits and political conflicts. @ecarmecolomina

(C) The author(s) 2020. This is an open access article licensed under a Creative Commons Attribution-NonCommercial-NoDerivs 4.0 Unported License 
Like a Venn diagram with multiple sets, European identity is constructed from multiple realities, overlapping with each other in complex ways: history and tradition, ethnicity and religion, migration and cultural exchange, cross-border friendships and intermarriage, in which every individual is embedded in a complex matrix of interconnections. However, this complex Europe is clashing with a counter-revolutionary moment (as the new populist forces would call it), determined to reinterpret the past and the present, to simplify realities and to hold on to a particular idea of Europe that no longer exists, if it ever did.

'There is a dark side to this sovereignty of remembrance, to Europe's self-definition as a lieu de la mémoire', George Steiner warned. ${ }^{1}$ There is a part of Europe willing to rewrite the past to transform the present and, for that purpose, they have taken the idea of a European identity hostage. It is the attempt to revive a Europe of supposedly strong and homogeneous states, where border control, restrictive migration policies, the pre-eminence of electoral majorities over minorities' rights and the clash of interests among EU member states and against EU institutions is the new normal. This defensive Europe occupies a new centrality, built around a smaller and more limited 'us'.

The European Union is a process, not an end in itself. The process of developing the union is based on consensus and the cession of elements of national sovereignty to seek the common good. For decades while this process continued, European identity was defined by shared European values. But now these values are questioned, and some member states are identifying the transfers of sovereignty to the EU level as a weakness, a loss of control. The consensus on what the EU is or should be is broken. There is no one single shared idea of Europe and its raison d'être. Everyone is choosing their own set within the diagram, potentially ignoring overlaps and excluding others. Belonging is an individual experience. Where do we feel we fit in? Where and who do we feel attached to? The sentiment of belonging to Europe has a lot to do with our individual experience of the European Union. It has a lot to do with how we perceive the benefits of EU integration, with our confidence in the near future, but also with our interest in travelling, studying and having personal or professional connections around the EU. It has a lot to do with emotions and perceptions. This is why across the board, attitudes to the EU in major cosmopolitan cities tend to be more favourable than in rural areas. (Divisions between countries are often smaller than the differences within them.)

The feeling of belonging to the EU is also transnational, less connected to national history than to the individual sense of the European Union as a space of opportunity giving wider horizons than the national, and also perhaps a safety network offering

${ }^{1}$ Steiner (2004). 
protection from destabilising forces. The more citizens feel the EU benefits them, the more they will favour its political project. The union needs to win perceptions back. Luuk van Middelaar praises 'the merit of the Community in the de-dramatisation of European policy' after the excess of drama that was experienced in the interwar period, when the settlement following the First World War led eventually to the Second. ${ }^{2}$ But in the present time of the politics of emotions, the EU will need more politics of results, a stronger delivery and a shared narrative if it is to strengthen its legitimacy and gain citizens' support.

\section{NO SOUTHERN FRONT}

For many years, the national political debate did not move at the same speed as decision-making processes in Brussels did. Political decisions were taken increasingly frequently not by EU states at a national level but by EU institutions, while reporting to the public remained limited to the national sphere. For decades, 'Brussels' was a sort of ambiguous political entity far, far away. As the debt crisis, which started to be felt in Southern European countries in the 1990s, worsened following the introduction of the single currency in 1999, the European Union loomed ever larger in citizens' daily worries. However, it was the outbreak of the 2008 financial crisis, post Lehman Brothers, and the political and economic decisions taken by a European Union in emergency mood, that brought a new perception of the EU's power and its capacity to intervene. Suddenly, everyone in Germany had an opinion on Greek economic problems; the Finnish learnt about the Spanish banking mess; we all followed the Cypriot crisis and the evolution of the Irish or Portuguese austerity measures. Therefore, the Europeanisation process, shaping people's awareness of the EU and its member states, became more important than before.

The paradox of this horizontal Europeanisation process lay in how this knowledge was framed. It never gave us a sense of common destiny. As the first rescue package for Greece was approved, a Nordic minister announced to the press that, finally, it was guaranteed that the Greek crisis would be 'only a Greek problem'. It was May 2010 and the bailout package, imposing draconian austerity measures on the Greeks, triggered a wave of protests and turmoil in Greece, which carried on for the next three years. It took a long time to understand that that early crisis would lead to a questioning of the entire European project. As Charlotte Galpin writes in her research on European identities, 'for the crisis to be understood as a common European crisis,

${ }^{2}$ Van Middelaar (2013: 303). 
therefore, it is likely that there is some sense of European identity already in existence', ${ }^{3}$ and this identity has been permanently under construction.

In the public discourse (media and politics), the economic crisis was always framed as somebody else's crisis. Explained by internal divides: North and South, debtors and creditors, core and periphery. However, within this dual narrative, the EU Southern political representatives did not attempt to build a common Southern identity. The peripheral countries of Mediterranean Europe were blamed as all of a kind, but their governments were unable to construct a common front to face the austerity policies imposed on them. They fled desperately from each other, trying to avoid being assimilated to the patient next door. The official discourse was differentiation. Even during the migrant crisis in recent years, Spain, Greece and Italy have responded differently; while Italy has been the most vocal in rejecting responsibility for arrivals, Greece has been unable to provide an adequate reception operation, and Spanish support for reallocation and rescue missions has fluctuated according to which party is in power. ${ }^{4}$

Was there any kind of peripheral identity during all those years? Were the different understandings and perceptions of the crisis influencing the construction of identity? And did they do so in a contradictory or opposite way in different parts of the European territory? People in the Mediterranean, exposed to austerity measures, had a shared collective feeling, not always in line with the narratives and the political priorities of their governments. The indignados movement, which began in Spain in 2011 and inspired similar protests across Southern Europe, is the best example of this; a cross-border wave of solidarity building a sort of shared identity among those hit by the crisis, from the young to pensioners and the unemployed. It was a moment of shared experiences of social crisis, street protests and labour mobility forced by the circumstances.

The 'no nos representan' [they do not represent us] claim of the indignados became the symbol of a crisis of representativeness that has ended up affecting not only politics but also the media and academia. The feeling of 'otherness' and the lines of exclusion have become stronger and deeper around the European Union and also in Southern Europe. The 'others' can be the migrants arriving on the Italian coast, singled out by the harsh rhetoric of the former Home Affairs Minister and Deputy Prime Minister Matteo Salvini; or those being chased by groups of Golden Dawn supporters in Athens. Or they can be 'internal others': this is the case for the recently elected Spanish far-right party, Vox, playing the card of an aggressive opposition to the separatist movement in Catalonia.

${ }^{3}$ Galpin (2017: 33).

${ }^{4}$ See Thieme et al. (2020) in this volume. 
The EU's political identity is always in-the-making because citizens' feelings of belonging have been evolving, and the concept and goals of the EU's integration are also at stake in certain governments. Too many internal 'others' are creating new tensions and divides: between Southern and Northern countries, between Eastern and Western ones; there are 'othering' processes towards migrants, towards minorities and between Brussels and some national capitals. The gap between the institutional development of Europe and the sense of sharing in a European identity has been growing, affecting the legitimacy of the European process.

\section{SOVEREIGNTY? WHICH SOVEREIGNTY?}

Euroscepticism is questioning the feeling of a European belonging. Many states have turned their national sovereignty into a symbol of their power. They have returned to national narratives of 'taking back control'. In a globalised world, in which the EU goal of ever-closer union has lost its appeal for many, some member states have made the exercise of their remaining powers a matter of strength. Sovereignty is the new magic word to sell Brexit, border controls, the resistance to mandatory quotas to resettle asylum seekers, and new nationalist political agendas. Many in the UK believed that the process of EU decision-making had undermined British parliamentary democracy. The Hungarian government is paying for public campaigns accusing the European Commission of seeking to flood the country with migrants. ${ }^{5} \mathrm{EU}$ institutions are seen today from some capitals as a threat to the sovereignty of states.

Old forms of solidarity, community decision-taking and sharing of responsibilities are understood within some European governments or political discourses as a limitation on sovereignty, as something imposed, not freely chosen. The EU must urgently find a way to reconcile national sovereignty with supranational powers; Southern needs, Eastern perceptions and Northern fears; the European project with its citizens. It is a sort of paradox that in the middle of a debate about virtual sovereignties on the internet, the latest narrative spreading among increasingly Eurosceptic governments is taking back control. Nativist and far-right forces have decided to reshape the European project in a clash of different visions. Nineteenth-century imaginaries are back in a union where big cities also claim a stronger political role, where some capitals have more inhabitants than certain member states but limited say in the EU's decision-making process. The mayors of London, Paris, Barcelona and Madrid have 
shown this new political will to empowerment, lobbying together in Brussels in favour of refuge cities or asking for better financing for local entities, for instance. ${ }^{6}$

'Europe has to become a more sovereign actor in international relations', Juncker claimed in his 2018 State of the Union speech. ${ }^{7}$ But how can a sovereign union emerge out of these internal divisions, to act decisively in the present shaken world order? Europe is a continent of movable borders - political, military or administrative; inner borders and, above all, invisible borders and mental walls. The European project is a history of overcoming divisions, but it is precisely at all these different boundaries that the EU is working out its future today. In Steiner's traversable geography, 'European history has been one of long marches', but now freedom of movement is at stake throughout this transit territory, challenging a political union permanently in transition. ${ }^{8}$ The European project collides with the complexity of being a supranational, transnational and intergovernmental offer in times where the politics of difference is gaining ground.

\section{REFERENCES}

European Commission (2019), Facts Matter: European Commission Responds to Hungarian Government Campaign, 28 February.

https://ec.europa.eu/commission/sites/beta-political/files/facts_matter_hungarian_government_ campaign_en.pdf

Galpin, C. (2017), The Euro Crisis and European Identities: Political and Media Discourse in Germany, Ireland and Poland (London, Palgrave Macmillan).

Junker, C. (2018), State of the Union 2018. https://ec.europa.eu/commission/priorities/state-union-speeches/state-union-2018_en

La Vanguardia (2016), 'Joint Manifesto of Barcelona, Madrid and Paris to Ask States for More Resources and Overcome their "Chronic Under-financing"', 14 October.

https://www.lavanguardia.com/local/barcelona/20161014/41996214729/manifiesto-conjuntobarcelona-madrid-paris-nueva-agenda-urbana.html

Papathanasiou, K. (2015), 'Mayors of Cities Hosting Refugees to EU: "Help Us to Help Them"', Greek Reporter, 13 September.

https://greece.greekreporter.com/2015/09/13/mayors-of-cities-hosting-refugees-to-eu-help-us-tohelp-them

Steiner, G. (2004), The Idea of Europe (Washington, DC, Nexus Institute).

Thieme, T., Kovacs, E. \& Ramakrishnan, K. (2020), 'Refugees as New Europeans, and the Fragile Line Between Crisis and Solidarity', Journal of the British Academy, 8(s1): 19-25. https://doi.org/10.5871/jba/008s2.000

Van Middelaar, L. (2013), The Passage to Europe: How A Continent Became A Union (New Haven, CT, Yale University Press).

${ }^{6}$ See Papathanasiou (2015) and La Vanguardia (2016).

${ }^{7}$ Junker (2018).

${ }^{8}$ Steiner (2004). 
To cite the article: Carme Colomina (2020), 'Rethinking belonging: a Mediterranean disaffection', Journal of the British Academy, 8(s1): 45-51.

DOI https://doi.org/10.5871/jba/008s1.045

Journal of the British Academy (ISSN 2052-7217) is published by

The British Academy, 10-11 Carlton House Terrace, London, SW1Y 5AH

www.thebritishacademy.ac.uk 
